\title{
How long do we have to treat overactive bladder syndrome (OAB)? A questionnaire survey of Canadian urologists and gynecologists
}

\author{
Mikolaj Przydacz, MD; Lysanne Campeau, MD¹; Jens-Erik Walter, MD²; Jacques Corcos, \\ $\mathrm{MD}^{1}$ \\ ${ }^{1}$ Department of Urology, Jewish General Hospital, McGill University; ${ }^{2}$ Department of Obstetrics and \\ Gynecology, McGill University Health Centre; Montreal, QC, Canada
}

Cite as: Can Urol Assoc J 2018 May 14; Epub ahead of print. http://dx.doi.org/10.5489/cuaj.5032

Published online May 14, 2018

$* * *$

\section{Abstract}

Introduction: Overactive bladder syndrome (OAB) is a highly prevalent and costly condition worldwide with negative impact on health-related quality of life. Although many guidelines exist and anticholinergics are considered to be the mainstay of pharmacological treatment, data are lacking regarding optimal treatment duration. Therefore, the aim of this study was to determine practice patterns of Canadian urologists and gynecologists regarding duration of OAB pharmacotherapy.

Methods: A 14-question survey was designed and survey links (English and French) were sent by email to all practicing urologists and gynecologists registered with the Canadian Urological Association and the Society of Obstetricians and Gynecologists of Canada via the associations’ email lists. The SurveyMonkey website served as platform where responses were collected and stored.

Results: A total of 301 physicians completed the questionnaire; 250 respondents (83\%) prescribe anticholinergics or beta-3-adrenoceptor agonist (mirabegron) in their practice, and 202 (81\%) start patient treatment with the lowest recommended medication dose. One hundred and twelve respondents (45\% of those who prescribe OAB medications) classified OAB pharmacotherapy as a lifelong management strategy, whereas 130 (52\% of those who prescribe OAB medications) think that OAB pharmacotherapy should be administered for a defined time period. Six-month and one-year time periods of drug treatments are the most commonly chosen answers given by physicians who treat their patients for a defined duration. Conclusion: There is general agreement among Canadian urologists and gynecologists that OAB treatment should be started with the lowest recommended medication dose. A slim majority of respondents think that OAB pharmacotherapy should be administered for a defined duration. 


\section{Introduction}

Overactive bladder syndrome (OAB) is defined by the International Continence Society as "urinary urgency, usually accompanied by frequency and nocturia, with or without urgency urinary incontinence, in the absence of urinary tract infection or other obvious pathologies". 1 Although OAB is not a life-threatening condition, its impact on quality of life (QoL) plays a major role in the decision to treat patients. It has been demonstrated that OAB significantly affects patients' health status, including physical, emotional, social, sexual and mental functioning. ${ }^{2-4}$ The chronic nature of this condition and its impact can be lifelong, negatively influencing the QoL of affected patients. ${ }^{5}$

For many years, antimuscarinic medications have been administered in the management of OAB symptoms and are currently recommended by the Canadian Urological Association as second-line treatment. ${ }^{6}$ The commercially-available beta-3-adrenoceptor agonist mirabegron is also currently recommended as an OAB pharmacotherapy option. Adverse event profile and possible contraindications should be considered when prescribing drugs of choice as second-line treatments. Presently-available OAB medications have proven their efficacy and are considered safe and well-tolerated overall. However, available literature does not provide recommendations about how long OAB should be managed pharmacologically.

The purpose of the present study is to ascertain current practices among Canadian urologists and gynecologists regarding $\mathrm{OAB}$ pharmacotherapy duration and review available data on this issue, to describe standards for this clinical concern.

\section{Methods}

Up to 14-question survey (depending on respondent answers to 3 skip logic questions) was designed to assess current Canadian practices in terms of OAB treatment duration. The institutional research ethics committee approved the study, and the principle of implied consent applied: thus, formal consent was not required. Study and consent details were clearly communicated before respondents began answering the questionnaire. Participation was voluntary, and no compensation was given. Survey links (English and French versions) were sent by email to all urologists and gynecologists registered with the Canadian Urological Association and the Society of Obstetricians and Gynecologists of Canada via the associations' email lists.

Specifically, 623 urologists and 790 gynecologists were invited to participate in the survey over a 3-month period. To increase the response rate, a reminder was sent 1 month after initial contact. The SurveyMonkey website served as platform where responses were collected and stored. The survey was mobile-responsive and optimized for desktop, tablet and mobile resolutions on Android and iOS devices. Responses were anonymous, and no personal information was collected.

Responses were summarized as descriptive statistics with proportions and percentages. All answers were included in the analysis, irrespective of whether the entire questionnaire was completed or not. Associations between demographic information and other responses were explored by chi square test with $p$ value set at $<0.05$ to define statistical significance. Data 
analysis was conducted with IBM SPSS Statistics, version 23.0 (IBM Corporation, Armonk, NY, USA).

\section{Results}

\section{Respondent characteristics}

301 physicians completed the questionnaire. The response rate for urologists and gynecologists was 31\% (190/623) and 14\% (111/790), respectively. Table 1 details the demographic characteristics of respondents.

\section{Specific questions}

250 respondents (83\%) prescribe anticholinergics or beta-3-adrenoceptor agonist (mirabegron) in their practice. They include 181 urologists (95\% of participating urologists) and 69 gynecologists (62\% of participating gynecologists). 202 (81\%) of these physicians start patient treatment with the lowest recommended medication dose. They include 140 urologists (77\% of those who prescribe OAB medications) and 62 gynecologists ( $90 \%$ of those who prescribe OAB medications). 34 urologists (19\%) and 6 gynecologists (5\%) declared that they start treatment with the highest recommended dose. In this specific group of respondents, the majority are male $(35,88 \%)$, with more than 10 years of clinical experience $(24,60 \%)$ but not specifically trained in functional urology with adequate fellowship (35, 88\%). Table 2 details the demographic characteristics of physicians who answered this question. Statistically significant correlations are found between specialization/gender and dose preference $(\mathrm{p}=0.04$ and $\mathrm{p}=0.0007$, respectively).

Participants were asked when they wish to see their patients after they started treatment and whether they realistically see them. Figure 1 presents the overall results. 110 respondents (44\%) wish to see their patients 4 to 8 weeks after they started treatment, whereas 96 (38\%) like to follow them up 8 to 12 weeks after initiating pharmacotherapy. In reality, however, 92 (37\%), 76 (30\%) and 69 (28\%) of respondents admitted to seeing their patients respectively 8-12 weeks, $>12$ weeks or 4-8 weeks, after they started treatment.

Further questions aimed to standardize OAB treatment duration. Physicians were queried whether OAB pharmacotherapy (medications) is needed lifelong or just for a defined time period. 112 (45\% of those who prescribe OAB medications) classified OAB pharmacotherapy as a lifelong management strategy. 130 (52\% of those who prescribe OAB medications) thought that $\mathrm{OAB}$ pharmacotherapy should be given for a defined time period. Table 3 reports the demographic aspects of this important question. Correlations between urologists and gynecologists are statistically significant $(\mathrm{p}=0.03)$.

In a group of respondents who think that OAB medications should be prescribed for a defined time period, the leading answers are "6 months" indicated by 53 physicians (41\%), and " 1 year" (32, 25\%). 99 (76\%) of physicians treating OAB for a defined time period suggest self-titration of the medication dose by patients, and 95 (73\%) see their patients at the end of treatment. Those who see their patients at the end of treatment were further asked about when it usually takes place. The leading answer is " 3 months" (32, 34\%) followed by "as needed basis” (21, 22\%), “1 month” (18, 19\%), “6 months” (12, 13\%), “1 year” (6, 6\%) 
and "immediately" (6, 6\%). The remaining physicians who treat OAB for a defined time period do not see patients or ask them to contact their family doctor if needed (35, 27\%).

\section{Discussion}

Pharmacotherapy has been at the center of treatment regimens for OAB management. The efficacy of antimuscarinics and mirabegron in OAB patients is well-documented. ${ }^{7-9}$ Whereas significant therapeutic effects are expected from most of these drugs after 7 days from the start of treatment ${ }^{10}$, data on treatment duration are sparse, although many clinical studies on OAB pharmacotherapy have been published.

The resolution of bothering symptoms has been given as one of the most common reasons for termination of treatment and may be achieved in more than one-third of OAB cases. ${ }^{11-15}$ Other common reasons for medication discontinuation are adverse effects and/or failure of expected clinical outcome. There is no consensus regarding the optimal duration of $\mathrm{OAB}$ treatment as, in the vast majority of available clinical trials, time periods of drug administration have been reported to range from 2 weeks to 12 months. ${ }^{16}$ It could be speculated that these studies may underestimate drug efficacy with short time periods of drug administration ${ }^{17-19}$, whereas treatment duration may be lengthier than necessary. ${ }^{20,21}$ To make matters even more complex, a specific definition of refractory OAB has not yet been established, resulting in different initiation time points with other medications or treatment modalities. $^{22}$

Canadian urologists and gynecologists generally agree that OAB treatment should be started with the lowest recommended medication dose. Our survey revealed that a slim majority of respondents ( $52 \%$ vs. $45 \%$ ) recommend OAB pharmacotherapy for a defined time period rather than lifelong. Interestingly, practice patterns of limited treatment duration are more typical for urologists than for gynecologists who prefer lifelong management. Furthermore, a higher percentage of urologists are more inclined to start treatment with the highest recommended medication dose. 6-month and 1-year time periods of OAB pharmacotherapy are the most commonly chosen answers by physicians who treat their patients for a defined time period (41\% and $25 \%$, respectively).

In current literature, the point at which to discontinue OAB pharmacotherapy and the time during which therapeutic efficacy is sustained after discontinuation of drug administration still remain in dispute. Hsiao et al. ${ }^{16}$, in their prospective study, proposed that minimal duration of antimuscarinic administration for OAB control should be 3 months. Enrolled patients ( $\mathrm{n}=164)$ were prescribed $5 \mathrm{mg}$ of solifenacin or $4 \mathrm{mg}$ of tolterodine extended release capsules daily and then monitored for a mean follow up of 1 month during a 6-month period in order to investigate treatment efficacy and discontinuation patterns.

Other researchers have assessed the effects of drug cessation after different treatment periods. Choo et al. ${ }^{23}$ measured changes in OAB symptoms in patients $(n=68)$ after discontinuation of successful 3-month treatment with $20 \mathrm{mg}$ of propiverine hydrochloride daily. 4 weeks after the cessation of antimuscarinic medication, the retreatment rate of $35.3 \%$ was due to worsening symptoms. Patients in the retreatment group were significantly older and had higher initial urgency scores than those requiring no further treatment. Patients who 
underwent urodynamic study $(\mathrm{n}=23)$ and demonstrated detrusor overactivity experienced more rapid symptom recurrence after medication discontinuation than those without detrusor overactivity. However, this correlation was not statistically significant. The authors concluded that, although 3 months of OAB pharmacotherapy was effective, it could not sustain symptom improvement for 1 month after discontinuation. These results line up with those reported by a British group with exactly the same time periods in patients $(n=251)$ treated with flexibledose fesoterodine (4 and $8 \mathrm{mg}$ ). ${ }^{24} \mathrm{OAB}$ symptoms were significantly improved after the 12 week treatment period but, at 4 weeks after fesoterodine discontinuation, $61 \%$ of patients showed increased micturition frequency, added severity of bladder-related problems and reduced health-related QoL. Dose escalation from 4 to $8 \mathrm{mg}$ at week 4 did not appear to influence the level of deterioration. In view of these findings, it can be stated that the beneficial effects on OAB symptoms and patient-reported outcomes after 12 weeks of treatment with an antimuscarinic drug are not maintained as early as 4 weeks after treatment stoppage.

Another study analyzed retreatment patterns in $108 \mathrm{OAB}$ patients randomized to 3 different groups with different time periods of OAB pharmacotherapy: tolterodine extended release $4 \mathrm{mg}$ daily. ${ }^{14}$ After the completion of 1-, 3- or 6-month treatment, patients stopped the medication and were followed up for another 3 months to assess symptom relapse and retreatment rates. 3 months after treatment discontinuation, $65 \%$ of patients requested retreatment and 62\% experienced symptom relapse, including increased micturition frequency, urgency episodes, urgency severity and incontinence events, compared to these parameters at the end of treatment. Furthermore, longer treatment did not prevent symptom relapse or retreatment. Nevertheless, the authors proposed that, in patients with improved symptoms, it might be possible to discontinue medication after consultation on the risks of symptom relapse and retreatment. They also stressed that physicians need to pay more attention to patients whose baseline QoL has deteriorated severely because of OAB symptoms, as they are at higher risk of retreatment.

A recently-published study enrolled $371 \mathrm{OAB}$ patients who took antimuscarinic agents for more than 12 weeks and responded favorably. ${ }^{25}$ They then discontinued antimuscarinics and were evaluated for recurrence of bothering symptoms at baseline, 1, 3 and 6 months, with a limited number of patients followed up for 12 months. Cumulative recurrence rates at 1,3 and 6 months were concurrent with earlier studies and were 25.6\%, 42.3\% and 52.2\%, respectively. However, a recurrence rate of $9.7 \%$ was seen in patients analyzed at the $12-$ month period. Patients without symptom recurrence until 6 months tended to persist with symptom-free status until 12 months of therapy discontinuation. These authors also demonstrated that patients who initially presented with concomitant urinary incontinence had greater risk of symptom recurrence.

A prospective randomized study of the antimuscarinics imidafenacin $0.1 \mathrm{mg}$ twice daily and solifenacin $5 \mathrm{mg}$ once daily gave astonishing results, with a 12-month treatment regimen in 109 patients. ${ }^{21}$ It disclosed that among those who discontinued treatment because of improvement, 3 of 12 patients on imidafenacin (25.0\%) and 7 of 13 patients on solifenacin 
(53.8\%) had recurring $\mathrm{OAB}$ symptoms and required medication within 12 months. Thus, it can be hypothesized that required treatment duration may vary between different OAB drugs. A retrospective study from the USA, with data from the IMS LifeLink Health Plan Claims Database, showed that $34.6 \%$ of 103,250 patients reinitiated treatment by the end of 2 years, with approximately one-fifth of patients (24.1\%) restarting after 1 year. ${ }^{26}$ Of those who reinitiated anticholinergic therapy, $65.6 \%$ did so with their index anticholinergic agent, whereas $34.4 \%$ went with a different anticholinergic.

A prospective study from Japan ( $\mathrm{n}=73$ ), assessing persistence rates of solifenacin $5 \mathrm{mg}$ daily treatment during a 3 -year period, demonstrated that $25 \%$ of patients required retreatment at an average 10 months after termination. ${ }^{12}$

Until now, there is paucity of data on the impact of physiotherapy on OAB recurrence after treatment cessation. Further research in this area is warranted as behavioral therapies, including pelvic floor muscle exercises, are relatively non-invasive and could benefit patient health overall.

To sum up, optimal duration of OAB pharmacotherapy and efficacy sustenance have not yet been determined. Based on our survey and literature review, it is proposed that OAB patients can be treated for their symptoms for 6-12 months and persistence to the drug therapy should be encouraged. Then, treatment cessation can be considered. If patients still need medications, lifelong or long-term OAB pharmacotherapy may be required. Thus, the optimal duration of OAB pharmacotherapy should be individualized as OAB encompasses an heterogeneous patient population with diverse symptoms, severities and pathophysiologies. Consideration should be given to possible etiologies and improving bladder health through preventive measures, to stop OAB progression. The presented approach could help physicians avoid the administration of ineffective medications and potential drug-related adverse effects.

\section{Conclusion}

There is general agreement among Canadian urologists and gynecologists that OAB treatment should be started with the lowest recommended medication dose. A slim majority of respondents think that $\mathrm{OAB}$ pharmacotherapy should be given for a defined time period. Practice patterns of limited treatment duration are more typical for urologists than for gynecologists who prefer lifelong management. 


\section{References}

1. Abrams P, Cardozo L, Fall M, et al. The standardisation of terminology of lower urinary tract function: report from the Standardisation Sub-committee of the International Continence Society. Neurourol Urodyn. 2002;21(2):167-78.

2. Kinsey D, Pretorius S, Glover L, et al. The psychological impact of overactive bladder: A systematic review. J Health Psychol. 2016;21(1):69-81.

3. Golabek T, Skalski M, Przydacz M, et al. Lower urinary tract symptoms, nocturia and overactive bladder in patients with depression and anxiety. Psychiatr Pol. 2016;50(2):417-30.

4. Przydacz M, Golabek T, Sobanski J, et al. Perception of lower urinary tract symptoms by psychiatrists in mentally affected patients. Psychiatr Pol. 2017;51(5):963-978.

5. Coyne KS, Wein A, Nicholson S, et al. Comorbidities and personal burden of urgency urinary incontinence: a systematic review. International journal of clinical practice. 2013;67(10):1015-33.

6. Corcos J, Przydacz M, Campeau L, et al. CUA guideline on adult overactive bladder. Canadian Urological Association journal = Journal de l'Association des urologues du Canada. 2017;11(5):E142-E73.

7. Madhuvrata P, Cody JD, Ellis G, et al. Which anticholinergic drug for overactive bladder symptoms in adults. Cochrane Database Syst Rev. 2012;1:Cd005429.

8. Chapple CR, Khullar V, Gabriel Z, et al. The effects of antimuscarinic treatments in overactive bladder: an update of a systematic review and meta-analysis. European urology. 2008;54(3):543-62.

9. Tubaro A, Batista JE, Nitti VW, et al. Efficacy and safety of daily mirabegron $50 \mathrm{mg}$ in male patients with overactive bladder: a critical analysis of five phase III studies. Ther Adv Urol. 2017;9(6):137-54.

10. Przydacz M, Corcos J. Onset of medication efficacy in patients with overactive bladder: What should we tell them? Neurourol Urodyn. 2016.

11. Sung HH, Han DH, Kim TH, et al. Interventions do not enhance medication persistence and compliance in patients with overactive bladder: a 24 weeks, randomised, open-label, multi-center trial. International journal of clinical practice. 2015;69(11):1309-15.

12. Tanaka Y, Tanuma Y, Masumori N. Long-term prospective study of the persistence of solifenacin succinate in previously untreated Japanese female patients with overactive bladder. Int J Urol. 2016;23(10):866-72.

13. Krhut J, Gartner M, Petzel M, et al. Persistence with first line anticholinergic medication in treatment-naive overactive bladder patients. Scandinavian journal of urology. 2014;48(1):79-83.

14. Lee YS, Choo MS, Lee JY, et al. Symptom change after discontinuation of successful antimuscarinic treatment in patients with overactive bladder symptoms: a randomised, multicentre trial. International journal of clinical practice. 2011;65(9):997-1004. 
15. Shim EJ, Yoo EH, Kim YM, et al. Factors affecting medication discontinuation in patients with overactive bladder symptoms. Obstet Gynecol Sci. 2015;58(6):507-13.

16. Hsiao SM, Liao CH, Lin HH, et al. Duration of Antimuscarinic Administration for Treatment of Overactive Bladder Before Which One Can Assess Efficacy: An Analysis of Predictive Factors. Int Neurourol J. 2015;19(3):171-7.

17. Jacquetin B, Wyndaele J. Tolterodine reduces the number of urge incontinence episodes in patients with an overactive bladder. Eur J Obstet Gynecol Reprod Biol. 2001;98(1):97-102.

18. Altan-Yaycioglu R, Yaycioglu O, Aydin Akova Y, et al. Ocular side-effects of tolterodine and oxybutynin, a single-blind prospective randomized trial. Br J Clin Pharmacol. 2005;59(5):588-92.

19. Herschorn S, Stothers L, Carlson K, et al. Tolerability of $5 \mathrm{mg}$ solifenacin once daily versus $5 \mathrm{mg}$ oxybutynin immediate release 3 times daily: results of the VECTOR trial. J Urol. 2010;183(5):1892-8.

20. Halaska M, Ralph G, Wiedemann A, et al. Controlled, double-blind, multicentre clinical trial to investigate long-term tolerability and efficacy of trospium chloride in patients with detrusor instability. World J Urol. 2003;20(6):392-9.

21. Yokoyama T, Koide T, Hara R, et al. Long-term safety and efficacy of two different antimuscarinics, imidafenacin and solifenacin, for treatment of overactive bladder: a prospective randomized controlled study. Urol Int. 2013;90(2):161-7.

22. Nitti VW, Kopp Z, Lin AT, et al. Can we predict which patient will fail drug treatment for overactive bladder? A think tank discussion. Neurourol Urodyn. 2010;29(4):652-7.

23. Choo MS, Song C, Kim JH, et al. Changes in overactive bladder symptoms after discontinuation of successful 3-month treatment with an antimuscarinic agent: a prospective trial. J Urol. 2005;174(1):201-4.

24. Khullar V, Cardozo L, Kelleher CJ, et al. Effects of drug cessation after flexible-dose fesoterodine in patients with overactive bladder. BJU Int. 2013;112(6):820-9.

25. Kim A, Lee KS, Kim TB, et al. Incidence and risk factors of recurrence of overactive bladder symptoms after discontinuation of successful medical treatment. Investig Clin Urol. 2017;58(1):42-7.

26. Chancellor MB, Migliaccio-Walle K, Bramley TJ, et al. Long-term patterns of use and treatment failure with anticholinergic agents for overactive bladder. Clin Ther. 2013;35(11):1744-51. 


\section{Figures and Tables}

Fig. 1. Distribution of answers to the questions: When do you wish to see your patients after starting their treatment? and When do you realistically see your patients after starting their treatment?

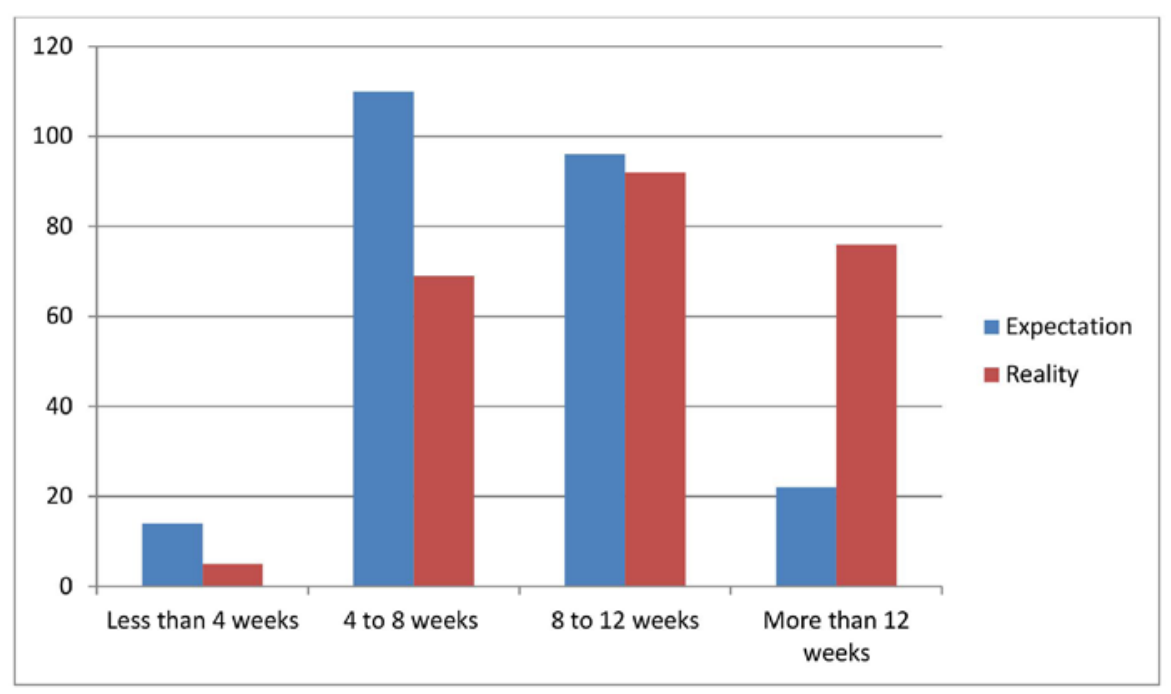

\begin{tabular}{|c|c|c|c|}
\hline Table 1. Demographic characteristics of respondents \\
\hline & $\begin{array}{c}\text { Urologists } \\
\mathbf{n = 1 9 0}(\mathbf{\%})\end{array}$ & $\begin{array}{c}\text { Gynecologists } \\
\mathbf{n = 1 1 1}(\mathbf{\%})\end{array}$ & $\begin{array}{c}\text { All respondents } \\
\mathbf{n = 3 0 1}(\mathbf{\%})\end{array}$ \\
\hline Gender & $144(76 \%)$ & $24(22 \%)$ & $168(56 \%)$ \\
\hline Male & $32(17 \%)$ & $82(74 \%)$ & $114(38 \%)$ \\
\hline Female & & & \\
\hline $\begin{array}{l}\text { Number of years of } \\
\text { practice }\end{array}$ & $41(22 \%)$ & $33(30 \%)$ & $74(25 \%)$ \\
\hline$<5$ & $36(19 \%)$ & $21(19 \%)$ & $57(19 \%)$ \\
\hline $5-10$ & $46(24 \%)$ & $35(32 \%)$ & $81(27 \%)$ \\
\hline $11-20$ & $53(28 \%)$ & $17(15 \%)$ & $70(23 \%)$ \\
\hline$>20$ & & & $90(30 \%)$ \\
\hline Practice & $53(28 \%)$ & $37(33 \%)$ & $122(41 \%)$ \\
\hline Academic & $83(44 \%)$ & $39(35 \%)$ & $70(23 \%)$ \\
\hline Community & $40(21 \%)$ & $30(27 \%)$ & \\
\hline $\begin{array}{l}\text { Academic and } \\
\text { community }\end{array}$ & & & \\
\hline
\end{tabular}




\begin{tabular}{|l|c|c|c|}
\hline Fellowship & $35(18 \%)$ & $7(6 \%)$ & $42(14 \%)$ \\
\hline $\begin{array}{l}\text { Functional } \\
\text { urology/neurourology- } \\
\text { trained }\end{array}$ & $73(38 \%)$ & $38(34 \%)$ & $111(37 \%)$ \\
\hline $\begin{array}{l}\text { Other fellowship- } \\
\text { trained }\end{array}$ & $68(36 \%)$ & $61(55 \%)$ & $129(43 \%)$ \\
\hline $\begin{array}{l}\text { Not-fellowship- } \\
\text { trained }\end{array}$ & & \\
\hline
\end{tabular}

Note: 19 physicians (6\%) did not fill out the demographic part of the questionnaire.

\begin{tabular}{|c|c|c|}
\hline & Lowest dose & $\begin{array}{c}\text { Highest } \\
\text { recommended dose }\end{array}$ \\
\hline Number of answers & $\begin{array}{c}202(81 \% \text { of } \\
\text { physicians treating } \\
\text { OAB) }\end{array}$ & $\begin{array}{l}40 \text { (16\% of physicians } \\
\text { treating OAB) }\end{array}$ \\
\hline \multicolumn{3}{|c|}{ Specialization $(\mathrm{p}=0.04)$} \\
\hline Urology & $\begin{array}{c}140(77 \% \text { of } \\
\text { urologists treating } \\
\text { OAB })\end{array}$ & $\begin{array}{l}34 \text { (19\% of urologists } \\
\text { treating OAB) }\end{array}$ \\
\hline Gynecology & $\begin{array}{c}62(56 \% \text { of } \\
\text { gynecologists treating } \\
\text { OAB })\end{array}$ & $\begin{array}{c}6(5 \% \text { of gynecologists } \\
\text { treating } \mathrm{OAB})\end{array}$ \\
\hline \multicolumn{3}{|l|}{ Gender $(p=0.0007)$} \\
\hline Male & $\begin{array}{c}122(78 \% \text { of male } \\
\text { physicians treating } \\
\text { OAB) }\end{array}$ & $\begin{array}{c}35(22 \% \text { of male } \\
\text { physicians treating } \\
\text { OAB })\end{array}$ \\
\hline Female & $\begin{array}{l}76(95 \% \text { of female } \\
\text { physicians treating } \\
\text { OAB) }\end{array}$ & $\begin{array}{c}4 \text { (5\% of female } \\
\text { physicians treating } \\
\text { OAB) }\end{array}$ \\
\hline \multicolumn{3}{|c|}{ Number of years of practice $(\mathrm{p}=0.23$ ) } \\
\hline$<5$ & $\begin{array}{l}55 \text { (92\% of those } \\
\text { practicing < } 5 \text { years } \\
\text { and treating OAB) }\end{array}$ & $\begin{array}{c}5(8 \% \text { of those } \\
\text { practicing }<5 \text { years and } \\
\text { treating } \mathrm{OAB})\end{array}$ \\
\hline $5-10$ & 36 (78\% of those & $10(22 \%$ of those \\
\hline
\end{tabular}




\begin{tabular}{|c|c|c|}
\hline & $\begin{array}{c}\text { practicing 5-10 years } \\
\text { and treating OAB) }\end{array}$ & $\begin{array}{c}\text { practicing 5-10 years } \\
\text { and treating } \mathrm{OAB} \text { ) }\end{array}$ \\
\hline $11-20$ & $\begin{array}{l}57 \text { (83\% of those } \\
\text { practicing } 11-20 \\
\text { years and treating } \\
\text { OAB) }\end{array}$ & $\begin{array}{l}12(17 \% \text { of those } \\
\text { practicing } 11-20 \text { years } \\
\text { and treating } \mathrm{OAB})\end{array}$ \\
\hline$>20$ & $\begin{array}{c}50(81 \% \text { of those } \\
\text { practicing }>20 \text { years } \\
\text { and treating OAB })\end{array}$ & $\begin{array}{c}12 \text { (19\% of those } \\
\text { practicing > } 20 \text { years } \\
\text { and treating OAB) }\end{array}$ \\
\hline \multicolumn{3}{|l|}{ Practice $(p=0.15)$} \\
\hline Academic & $\begin{array}{c}67 \text { (91\% of academics } \\
\text { treating OAB) }\end{array}$ & $\begin{array}{c}7 \text { (9\% of academics } \\
\text { treating OAB) }\end{array}$ \\
\hline Community & $\begin{array}{c}86 \text { (80\% of those } \\
\text { working at } \\
\text { community hospitals } \\
\text { and treating OAB) }\end{array}$ & $\begin{array}{l}21 \text { ( } 20 \% \text { of those } \\
\text { working at community } \\
\text { hospitals and treating } \\
\text { OAB) }\end{array}$ \\
\hline $\begin{array}{l}\text { Academic and } \\
\text { community }\end{array}$ & $\begin{array}{c}45 \text { ( } 80 \% \text { of those } \\
\text { working at either } \\
\text { academic or } \\
\text { community hospitals } \\
\text { and treating OAB) }\end{array}$ & $\begin{array}{l}11 \text { ( } 20 \% \text { of those } \\
\text { working at either } \\
\text { academic or } \\
\text { community hospitals } \\
\text { and treating OAB) }\end{array}$ \\
\hline \multicolumn{3}{|l|}{ Fellowship $(\mathrm{p}=0.41)$} \\
\hline $\begin{array}{l}\text { Functional } \\
\text { urology/neurourology- } \\
\text { trained }\end{array}$ & $\begin{array}{c}38 \text { (90\% of functional } \\
\text { urology-trained } \\
\text { physicians })\end{array}$ & $\begin{array}{c}4 \text { (10\% of functional } \\
\text { urology-trained } \\
\text { physicians) }\end{array}$ \\
\hline $\begin{array}{l}\text { Other fellowship- } \\
\text { trained }\end{array}$ & $\begin{array}{c}74 \text { (82\% of other } \\
\text { fellowship-trained } \\
\text { physicians treating } \\
\text { OAB) }\end{array}$ & $\begin{array}{c}16 \text { (18\% of other } \\
\text { fellowship-trained } \\
\text { physicians treating } \\
\text { OAB) }\end{array}$ \\
\hline $\begin{array}{l}\text { Not-fellowship- } \\
\text { trained }\end{array}$ & $\begin{array}{c}86 \text { (82\% of not- } \\
\text { fellowship-trained } \\
\text { physicians treating } \\
\text { OAB) }\end{array}$ & $\begin{array}{c}19 \text { (18\% of not- } \\
\text { fellowship-trained } \\
\text { physicians treating } \\
\text { OAB) }\end{array}$ \\
\hline
\end{tabular}




\begin{tabular}{|c|c|c|}
\hline \multicolumn{3}{|c|}{$\begin{array}{l}\text { Table 3. Demographic characteristic of respondents who answered } \\
\text { the question: Do you think that OAB pharmacotherapy } \\
\text { (medications) needs to be given lifelong or for a defined time period? }\end{array}$} \\
\hline & Lifelong & Time period \\
\hline Number of answers & $\begin{array}{l}112(45 \% \text { of } \\
\text { physicians treating } \\
\text { OAB })\end{array}$ & $\begin{array}{c}130 \text { (52\% of physicians } \\
\text { treating OAB) }\end{array}$ \\
\hline \multicolumn{3}{|c|}{ Specialization $(\mathrm{p}=0.03)$} \\
\hline Urology & $\begin{array}{c}73 \text { (40\% of urologists } \\
\text { treating OAB) }\end{array}$ & $\begin{array}{c}101 \text { (56\% of urologists } \\
\text { treating OAB) }\end{array}$ \\
\hline Gynecology & $\begin{array}{l}39(57 \% \text { of } \\
\text { gynecologists treating } \\
\text { OAB })\end{array}$ & $\begin{array}{c}29(42 \% \text { of } \\
\text { gynecologists treating } \\
\text { OAB })\end{array}$ \\
\hline \multicolumn{3}{|l|}{ Gender $(\mathrm{p}=0.43)$} \\
\hline Male & $\begin{array}{l}70(45 \% \text { of male } \\
\text { physicians treating } \\
\text { OAB) }\end{array}$ & $\begin{array}{l}87(55 \% \text { of male } \\
\text { physicians treating } \\
\text { OAB) }\end{array}$ \\
\hline Female & $\begin{array}{l}40(50 \% \text { of female } \\
\text { physicians treating } \\
\text { OAB })\end{array}$ & $\begin{array}{l}40(50 \% \text { of female } \\
\text { physicians treating } \\
\text { OAB })\end{array}$ \\
\hline \multicolumn{3}{|c|}{ Number of years of practice $(\mathrm{p}=0.08)$} \\
\hline$<5$ & $\begin{array}{l}31(52 \% \text { of those } \\
\text { practicing }<5 \text { years } \\
\text { and treating } \mathrm{OAB})\end{array}$ & $\begin{array}{c}29(48 \% \text { of those } \\
\text { practicing }<5 \text { years and } \\
\text { treating OAB })\end{array}$ \\
\hline $5-10$ & $\begin{array}{l}15 \text { (33\% of those } \\
\text { practicing } 5-10 \text { years } \\
\text { and treating OAB) }\end{array}$ & $\begin{array}{c}31 \text { (67\% of those } \\
\text { practicing 5-10 years } \\
\text { and treating OAB) }\end{array}$ \\
\hline $11-20$ & $\begin{array}{l}38 \text { (55\% of those } \\
\text { practicing } 11-20 \\
\text { years and treating } \\
\text { OAB) }\end{array}$ & $\begin{array}{l}31 \text { (45\% of those } \\
\text { practicing } 11-20 \text { years } \\
\text { and treating OAB) }\end{array}$ \\
\hline$>20$ & $\begin{array}{l}26(42 \% \text { of those } \\
\text { practicing }>20 \text { years } \\
\text { and treating OAB) }\end{array}$ & $\begin{array}{l}36(58 \% \text { of those } \\
\text { practicing }>20 \text { years } \\
\text { and treating OAB) }\end{array}$ \\
\hline \multicolumn{3}{|l|}{ Practice $(p=0.52)$} \\
\hline Academic & $\begin{array}{c}32(43 \% \text { of academics } \\
\text { treating } \mathrm{OAB})\end{array}$ & $\begin{array}{c}42(57 \% \text { of academics } \\
\text { treating } \mathrm{OAB})\end{array}$ \\
\hline Community & $\begin{array}{c}54 \text { (50\% of those } \\
\text { working at }\end{array}$ & $\begin{array}{c}53 \text { (50\% of those } \\
\text { working at community }\end{array}$ \\
\hline
\end{tabular}




\begin{tabular}{|c|c|c|}
\hline & $\begin{array}{c}\text { community hospitals } \\
\text { and treating } \mathrm{OAB} \text { ) }\end{array}$ & $\begin{array}{l}\text { hospitals and treating } \\
\text { OAB) }\end{array}$ \\
\hline $\begin{array}{l}\text { Academic and } \\
\text { community }\end{array}$ & $\begin{array}{l}24 \text { (43\% of those } \\
\text { working at either } \\
\text { academic or } \\
\text { community hospitals } \\
\text { and treating OAB) }\end{array}$ & $\begin{array}{l}32 \text { (57\% of those } \\
\text { working at either } \\
\text { academic or } \\
\text { community hospitals } \\
\text { and treating OAB) }\end{array}$ \\
\hline \multicolumn{3}{|l|}{ Fellowship $(\mathrm{p}=0.08)$} \\
\hline $\begin{array}{l}\text { Functional } \\
\text { urology/neurourology- } \\
\text { trained }\end{array}$ & $\begin{array}{c}24 \text { (57\% of functional } \\
\text { urology-trained } \\
\text { physicians) }\end{array}$ & $\begin{array}{c}18 \text { (43\% of functional } \\
\text { urology-trained } \\
\text { physicians) }\end{array}$ \\
\hline $\begin{array}{l}\text { Other fellowship- } \\
\text { trained }\end{array}$ & $\begin{array}{c}34 \text { (38\% of other } \\
\text { fellowship-trained } \\
\text { physicians treating } \\
\text { OAB) }\end{array}$ & $\begin{array}{l}56(62 \% \text { of other } \\
\text { fellowship trained } \\
\text { physicians treating } \\
\text { OAB) }\end{array}$ \\
\hline $\begin{array}{l}\text { Not-fellowship- } \\
\text { trained }\end{array}$ & $\begin{array}{c}52 \text { (50\% of not- } \\
\text { fellowship-trained } \\
\text { physicians treating } \\
\text { OAB) }\end{array}$ & $\begin{array}{c}53 \text { (50\% of not- } \\
\text { fellowship-trained } \\
\text { physicians treating } \\
\text { OAB) }\end{array}$ \\
\hline
\end{tabular}

